\title{
Genotypic Analysis of the Virulence and Antibiotic Resistance Genes in Campylobacter species in silico
}

\section{Nusrat Nahar* and Ridwan Bin Rashid}

Computational Chemistry and Bioinformatics Laboratory, Department of Pharmacy, State University of Bangladesh, Dhaka, Bangladesh

\begin{abstract}
Campylobacter species is responsible for 400-500 million diarrhea cases worldwide every year. Emergence of antibiotic resistance has further complicated the scenario. A wide range of virulence factors and resistance genes are present in Campylobacter species and it is hypothesized there are genotypic variations in the prevalence of these genes. The study was conducted to investigate the presence of virulence and antibiotic resistance genes as well as to investigate difference in prevalence rate based on genotype through in silico tools. Among 26 species studied, sixteen isolates $(61.54 \%)$ had the $c d t B$ gene that breaks the double helix bonds. The $c d t A$ genes were detected in ten $(38.46 \%)$ C. jejuni strains while fifty percent $(n=13)$ isolates harbored the $c d t C$ genes. Ten isolates that harboured all three adjacent $c d t$ genes were most toxigenic. The lipo-oligosaccharides associated genes, cgtB and $w / a N$, responsible for $\beta-1,3$ galactosyltransferase production, were found in $7.69 \%$ and $30.77 \%$ of the isolates, respectively. About $57.69 \%$ isolates expressed waaC genes. Invasion protein ciaB, outer membrane phospholipase A pldA and IV secretory protein virB11 were found in $53.85 \%, 34.62 \%$ and $7.69 \%$ of the isolates, respectively. Six isolates $(23.08 \%)$ expressed both tetO and tet $A$ genes while one isolate expressed only tet $A$ resistance gene. Seven isolates $(26.92 \%)$ had changes in gyrB genes that conferred the fluoroquinolone resistance. In silico PFGE typing found that genotype 3 contained all the virulence genes except $c g t B$ gene while genotype 3 and 4 contained mutated gyrB gene. Genotype 1 and 5 contained no virulence and antibiotic resistance genes. Our data helps to predict the possibility of the presence of virulence and antibiotic resistance genes and helps to select appropriate antibiotic that are more efficacious.
\end{abstract}

Keywords: Antibiotic resistance genes; Campylobacter; Genotype; PCR; PFGE; Virulence genes

\section{Introduction}

Gram-negative Campylobacter species is responsible for traveler's diarrhea and gastroenteritis in humans [1,2]. Campylobacter is responsible for 400-500 million diarrhea cases worldwide every year [3]. Guillain-Barré syndrome is caused by $C$ jejuni [4] but virulence mechanisms are not well understood. Several studies found that contaminated food, raw milk, water, vegetables, seafood, atmospheric modified packed meat transmitted the zoonotic pathogen Campylobacter to humans during consumption or handling process $[1,2,5]$. Several investigations found that main source of food-borne human campylobacteriosis is poultry and poultry products [6,7]. During slaughtering, the intestinal tract of healthy birds and raw meat are contaminated with thermophilic Campylobacter species. In slaughter house, faeces and processing facilities during the evisceration process contaminated swine carcasses that ultimately leads to contaminated food products [8-10].

The mechanism of Campylobacter gastroenteritis in humans is not well known that limits the prevention of campylobacteriosis. Virulence factors such as motility and adherence of bacteria to the intestinal mucosa, invasion of enterocyte and toxin production may contribute to the pathogenicity of campylobacteriosis infections [11,12]. The most common virulence factor in Campylobacter species, the Cytolethal Distending Toxin (CDT) causes cellular distension which eventually leads to cell death [13]. The CDT has 3 subunits namely CdtA, CdtB, $\mathrm{CdtC}$. The CdtB is the active subunit whereas CdtA and CdtC makes up the B subunit responsible for binding to susceptible cells [14]. Active toxin component of $c d t B$ gene disrupted the double helix bonds in the nucleus and blocked the cell cycle $[15,16]$. The $w l a N, \operatorname{cgt} B$ and $w a a C$ are LOS (lipo-oligosaccharides) associated genes while $w l a N$ and $\operatorname{cgt} B$ are involved in $\beta-1,3$ galactosyltransferase production [17]. These two genes are associated with waaC gene (which encodes heptosyltransferase I) and connected with the Guillain-Barre' and Miller-Fischer syndromes $[18,19]$. GBS and other neuropathic conditions are caused because of molecular mimicry of Campylobacter lipooligosaccharide (LOS) with the carbohydrate moiety of gangliosides. The waaC gene, which encodes heptosyltransferase I, is responsible for transferring the first l-glycerod-manno-heptose residue to the inner core of LOS [20]. The wlaN gene, which encodes a beta-1,3 galactosyltransferase, is responsible for biosynthesis GM1-like structure [18] whereas $\operatorname{cgtB}$ (which encodes another beta-1,3 galactosyltransferase) catalyzes the biosynthesis of the carbohydrate moieties analogous to GM2 [18,21].

Invasion protein $(\mathrm{ciaB})$, outer membrane phospholipase A ( $p l d A)$, and type IV secretory protein (virB11) genes associated with bacterial invasion on epithelial cells, were found by previous study [22] but their functions are not well known. Phospholipase A, pldA was found to be expressed in invasive strains [23].

Several studies found that multidrug-resistant Campylobacter has increased worldwide due to misuse of antibiotics [24,25]. For the treatment of systemic campylobacteriosis infections, other antibiotics such as gentamicin, tetracycline and ampicillin have been used [26,27].

${ }^{*}$ Corresponding author: Nusrat Nahar, Computational Chemistry and Bioinformatics Laboratory, Department of Pharmacy, State University of Bangladesh, Dhaka, Bangladesh, Tel: 09613782338; E-mail: nusratnahar17@gmail.com

Received January 02, 2018; Accepted January 22, 2018; Published January 29 2018

Citation: Nahar N, Rashid RB (2018) Genotypic Analysis of the Virulence and Antibiotic Resistance Genes in Campylobacter species in silico. J Bioanal Biomed 10: 13-23. doi:10.4172/1948-593X.1000199

Copyright: (c) 2018 Nahar N, et al. This is an open-access article distributed unde the terms of the Creative Commons Attribution License, which permits unrestricted use, distribution, and reproduction in any medium, provided the original author and source are credited. 
Citation: Nahar N, Rashid RB (2018) Genotypic Analysis of the Virulence and Antibiotic Resistance Genes in Campylobacter species in silico. J Bioanal Biomed 10: 13-23. doi:10.4172/1948-593X.1000199

Fluoroquinolones, followed by tetracyclines, are the most commonly used antibiotics in the poultry industry [28] where Campylobacter is ubiquitous. It can be inferred that over use of tetracyclines and fluoroquinolones have contributed to their resistance. Mutations in gyrA and gyrB regions of DNA gyrase and been held accountable for resistance against fluoroquinolones such as ciprofloxacin [29]. Majority of fluoroquinolone resistance of Campylobacter is developed by amino acid substitution at Thr-86 to Ilu though alternative mutation at Asp90 and double mutation at Thr-86 and Pro-104 were also reported [30].

Resistance to tetracycline might be due to efflux, enzymatic alternation of antibiotic or by ribosomal protection. The tet $A$ gene encodes efflux protein associated with pumping out tetracyclines out of the cell [31]. The tetO causes resistance by ribosomal protection whereas tetX gene encodes enzymes responsible for target modification [31]. Scientists identified that tetO protein recognized and bound with an open A site of the bacterial ribosome and conformational changes occurred that released bound tetracycline molecules [32]. Previous findings found that tet $\mathrm{O}$ also inhibited tRNA accommodation into the ribosomal A site and inhibited protein elongation phase [33].

Pulsed Field Gel Electrophoresis (PFGE) is considered as the gold standard for genotyping [34] and in silico data matched to that obtained in conventional method [35]. Our data helps to predict virulence and antimicrobial resistance profile of twenty-six Campylobacter species through in silico tools and also analyzes how pulsed-field gel electrophoresis (PFGE) typing distributed the virulence and resistance genes within the genotypes. The virulence and resistance profile of future isolates with known genotype can be predicted according to our data.

\section{Materials and Methods}

\section{Strains used in the study}

Strains used in the study are summarized in Table 1. All strains were of human/ animal origin.

\section{Primers used in the study}

Primers used for detection of virulence and antibiotic resistance genes are summarized in Tables 2 and 3 [36-43].

\section{PCR amplification}

In silico PCR amplification was done in the website http://insilico. ehu.eus/PCR/ [35,44].

\section{PFGE digestion}

An online software http://insilico.ehu.es/digest/wasdesigned for insilico pulsed-field gel electrophoresis (PFGE) digestion [35,44]. Restriction enzyme KpnI recognized the restriction sequenceG_ GTAC'C of Campylobacter species. Dendrogram construction was done in the website.

\section{Results and Discussion}

\section{Genetic diversity of isolates}

A total of 26 isolates were subjected to in silico pulsed-field gel electrophoresis (PFGE) analysis with $K p n I$ restriction digestion that recognized the sequence G_GTAC'C of Campylobacter species. Band fragments were separated in $1.2 \%$ agarose gel and lambda ladder compared the band size. In silico PFGE typing grouped 26 isolates into five genotypes using $80 \%$ as a cutoff value (Figure 1). Genotype 3 was most prevalent followed by genotype 4 and 2 . Fifty percent $(n=13)$ isolates were present in genotype 3 whereas genotype 4 contained

\begin{tabular}{|c|c|}
\hline $\begin{array}{c}\text { Serial } \\
\text { number }\end{array}$ & Isolate \\
\hline 1 & NC_022660 Campylobacter coli 15-537360 \\
\hline 2 & NC_022132 Campylobacter coli 76339 \\
\hline 3 & NC_022347 Campylobacter coli CVM N29710 \\
\hline 4 & NC_009802 Campylobacter concisus 13826 \\
\hline 5 & NC_009715 Campylobacter curvus 525.92 \\
\hline 6 & NC_008599 Campylobacter fetus subsp. fetus $82-40$ \\
\hline 7 & NC_009714 Campylobacter hominis ATCC BAA-381 \\
\hline 8 & NC_021834 Campylobacter jejuni 32488 \\
\hline 9 & NC_022529 Campylobacter jejuni 4031 \\
\hline 10 & NC_003912 Campylobacter jejuni RM1221 \\
\hline 11 & NC_009707 Campylobacter jejuni subsp. doylei 269.97 \\
\hline 12 & NC_022362 Campylobacter jejuni subsp. jejuni 00-2425 \\
\hline 13 & NC_022352 Campylobacter jejuni subsp. jejuni 00-2426 \\
\hline 14 & NC_022351 Campylobacter jejuni subsp. jejuni 00-2538 \\
\hline 15 & NC_022353 Campylobacter jejuni subsp. jejuni 00-2544 \\
\hline 16 & NC_008787 Campylobacter jejuni subsp. jejuni 81-176 \\
\hline 17 & NC_009839 Campylobacter jejuni subsp. jejuni 81116 \\
\hline 18 & NC_017279 Campylobacter jejuni subsp. jejuni IA3902 \\
\hline 19 & NC_014802 Campylobacter jejuni subsp. jejuni ICDCCJ07001 \\
\hline 20 & NC_017280 Campylobacter jejuni subsp. jejuni M1 \\
\hline 21 & NC_002163 Campylobacter jejuni subsp. jejuni NCTC 11168 \\
\hline 22 & NC_018521 Campylobacter jejuni subsp. jejuni NCTC 11168-BN148 \\
\hline 23 & NC_018709 Campylobacter jejuni subsp. jejuni PT14 \\
\hline 24 & NC_017281 Campylobacter jejuni subsp. jejuni S3 \\
\hline 25 & NC_012039 Campylobacter lari RM2100 \\
\hline 26 & NC_022759 Campylobacter sp. 03-427 \\
\hline
\end{tabular}

Table 1: Name of the isolate.

\begin{tabular}{|c|c|c|c|}
\hline & $\begin{array}{c}\text { Primer sequence } \\
\left(5^{\prime}-3^{\prime}\right)\end{array}$ & $\begin{array}{l}\text { Amplicon size } \\
\text { (bp) }\end{array}$ & References \\
\hline$c d t A$ & $\begin{array}{l}\text { CCT TGT GAT GCA AGC AAT C } \\
\text { ACA CTC CAT TTG CTT TCT G }\end{array}$ & 370 & [36] \\
\hline$c d t B$ & $\begin{array}{l}\text { CAGAAAGCA AAT GGA GTG TT } \\
\text { AGC TAA AAG CGG TGG AGT AT }\end{array}$ & 620 & [12] \\
\hline$c d t C$ & $\begin{array}{l}\text { TTGGCATTATAGAAAATA CAG TT } \\
\text { CGATGAGTTAAAACAAAAAGATA }\end{array}$ & 182 & [12] \\
\hline $\operatorname{cgtB}$ & $\begin{array}{l}\text { TTAAGAGCAAGATATGAAGGTG } \\
\text { GCACATAGAGAACGCTACAA }\end{array}$ & 562 & [18] \\
\hline wlaN & $\begin{array}{l}\text { TGCTGGGTATACAAAGGTTGTG } \\
\text { AATTTTGGATATGGGTGGGG }\end{array}$ & 330 & [37] \\
\hline waaC & $\begin{array}{l}\text { TAATGAAAATAGCAATTGTTCGT } \\
\text { GATACAAAAATCACTTTTATCGA }\end{array}$ & 971 & [38] \\
\hline virB11 & $\begin{array}{l}\text { GAACAGGAAGTGGAAAAACTAGC } \\
\text { TTCCGCATTGGGCTATATG }\end{array}$ & 708 & [39] \\
\hline pldA & $\begin{array}{l}\text { AAG AGT GAG GCG AAA TTC CA } \\
\text { GCA AGA TGG CAG GAT TAT CA }\end{array}$ & 385 & [40] \\
\hline$c i a B$ & $\begin{array}{l}\text { TGC GAG ATT TTT CGA GAA TG } \\
\text { TGC CCG CCT TAG AAC TTA CA }\end{array}$ & 527 & [40] \\
\hline iam & $\begin{array}{l}\text { GCGCAAATATTATCACCC } \\
\text { TTCACGACTACTACTATGCGG }\end{array}$ & 518 & [41] \\
\hline
\end{tabular}

Table 2: Primers for the detection of virulence genes.

about $26.92 \%(n=7)$ of the isolates. Genotype 1 and 3 and harboured about $3.85 \%$ of the isolates (Figure 2).

\section{Genotypic distribution of Cytolethal Distending Toxin associated $c d t$ genes}

Toxigenic activity of Campylobacter species is determined by cytolethal distending toxin which is composed of the $c d t$ gene cluster containing three adjacent genes $(c d t A, c d t B$ and $c d t C)$. It was found that 
Citation: Nahar N, Rashid RB (2018) Genotypic Analysis of the Virulence and Antibiotic Resistance Genes in Campylobacter species in silico. J Bioanal Biomed 10: 13-23. doi:10.4172/1948-593X.1000199

three $c d t$ genes determined the functional activity of CDT toxin [15]. Previously researchers identified that $c d t A$ and $c d t C$ are responsible for binding to target whereas the $c d t B$ encoded active subunit of the toxin $[15,45]$. Sixteen isolates $(61.54 \%)$ had the $c d t B$ gene with 620 bp PCR product (Figure 3). Only Campylobacter jejuni subsp. doylei 269.97 didn't harbour $c d t B$ gene out of the isolates studied. The $c d t A$ gene was detected in ten (38.46\%) C. jejuni strains with 370 bp gene product (Figure 4) while fifty percent $(n=13)$ isolates harboured the $c d t C$ genes. These isolates gave a $182 \mathrm{bp}$ amplicon (Figure 5). The present study found ten isolates that harboured all three adjacent $c d t$ genes and these were considered as most toxigenic strains. Genotype 1 and 5 contained no $c d t$ genes (Figure 6) and hence such isolates are unlikely to cause gastroenteritis. On the other hand, genotype 2, 3 and 4 contained all three $c d t$ genes. All the isolates present in genotype 3 carried $c d t B$ genes while about $61.54 \%$ and $76.92 \%$ isolates present in genotype 3 expressed $c d t A$ and $c d t C$ genes, respectively. About $28.58 \%$ in genotype 4 expressed $c d t B$ and $c d t C$ genes while $14.29 \%$ isolates harboured $c d t A$ gene in genotype 4 . Twenty-five percent isolates in genotype 2 carried all three $c d t$ genes. It must be noted that $c d t B$ alone can cause cytotoxicity [46]. Hence isolates with only $c d t B$ gene can cause gastroenteritis irrespective of the $c d t A$ and $c d t C$ although potency of toxin might be compromised. Thus all isolates from genotype 3 will cause diarrhea.

\section{Genotypic distribution of genes associated with Guillain- Barré syndrome}

The genes $\operatorname{cgtB}$, wlaN and waaC are associated with GBS and other neuropathic conditions through molecular mimicry of LOS with gangliosides. The $c g t B$ gene was detected in only two isolates and

\begin{tabular}{|c|c|c|c|}
\hline Gene & $\begin{array}{c}\text { Primer sequence } \\
\text { (5'-3') }\end{array}$ & $\begin{array}{c}\text { Amplicon size } \\
\text { (bp) }\end{array}$ & References \\
\hline tetO & $\begin{array}{c}\text { GGCGTTTTGTTTATGTGCG } \\
\text { ATGGACAACCCGACAGAAGC }\end{array}$ & 559 & {$[42]$} \\
\hline tetA & $\begin{array}{c}\text { GCTCACGTTGACGCAGGAAAG } \\
\text { ATC GTC ATT GTC CGT TAC }\end{array}$ & 486 & {$[43]$} \\
\hline gyrA & $\begin{array}{c}\text { ACGCAAGAGATGGTT } \\
\text { GCTGCGATGCGTTATACTGA }\end{array}$ & 270 & {$[30]$} \\
\hline gyrB & $\begin{array}{c}\text { ATGGCAGCTAGAGGAAGAGA } \\
\text { GTGATCCATCAACATCCGCA }\end{array}$ & 382 & {$[30]$} \\
\hline
\end{tabular}

Table 3: Primers for detection of antibiotic resistance genes.

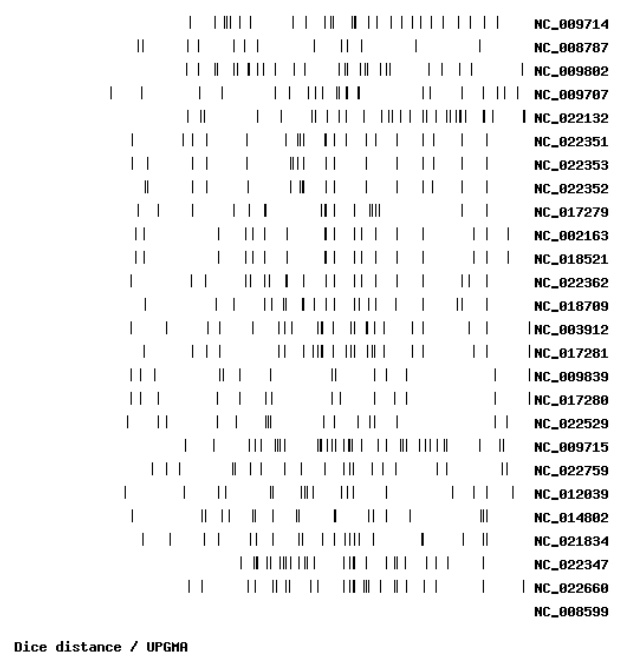

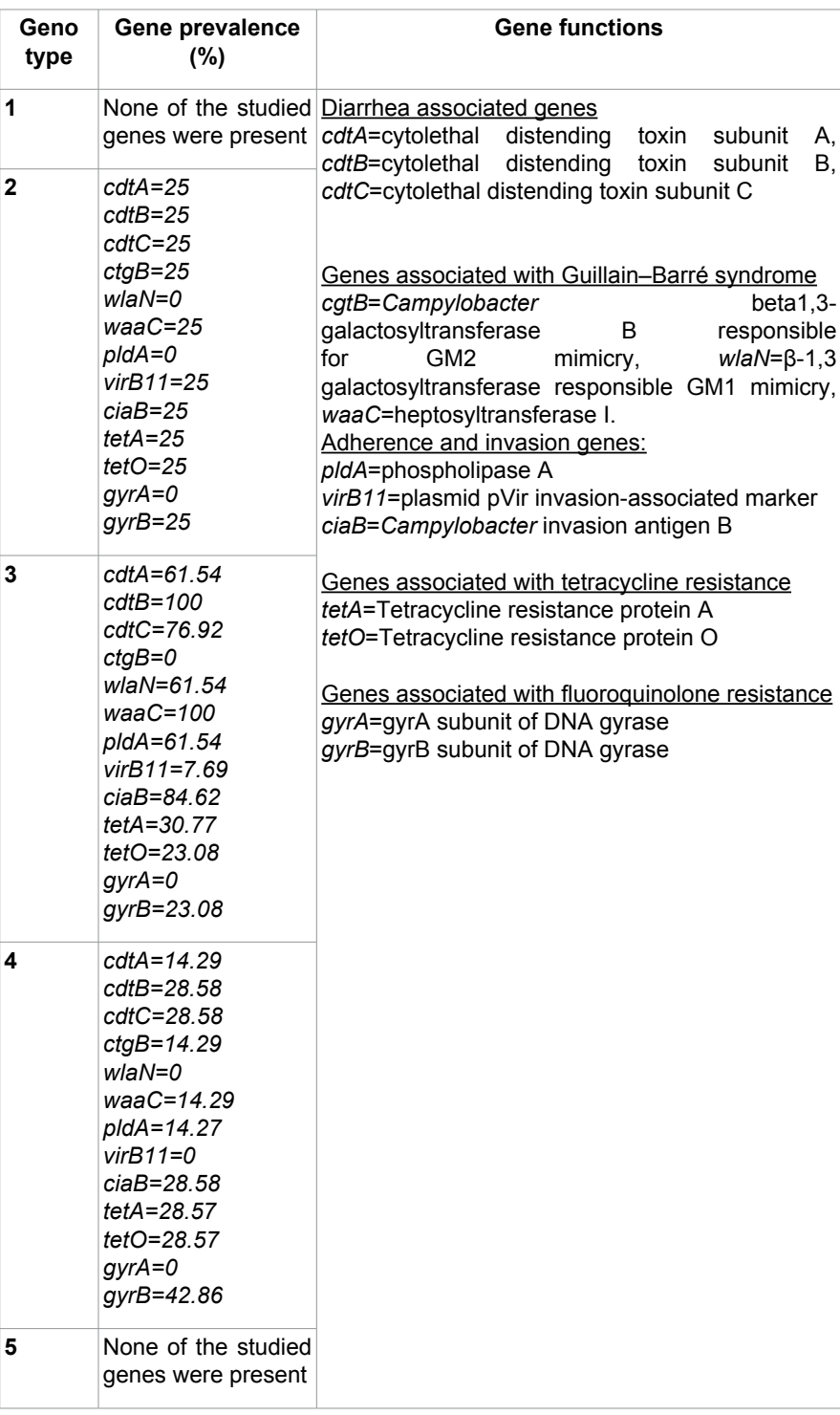

Table 4: Summary of the results.

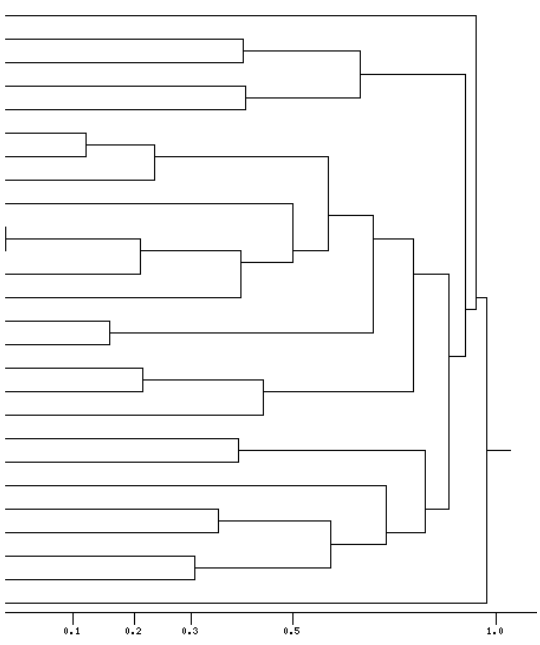

Figure 1: Phylogenetic diversity of Campylobacter species identified by PFGE analysis. 


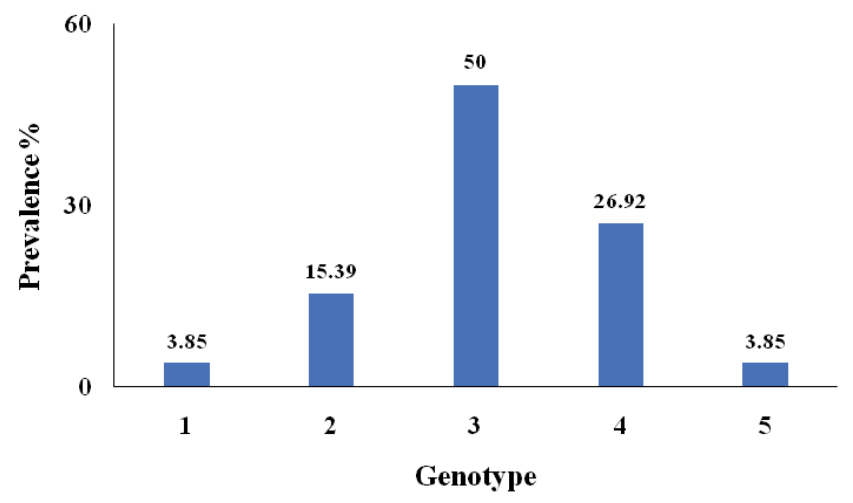

Figure 2: Prevalence of genotypes.

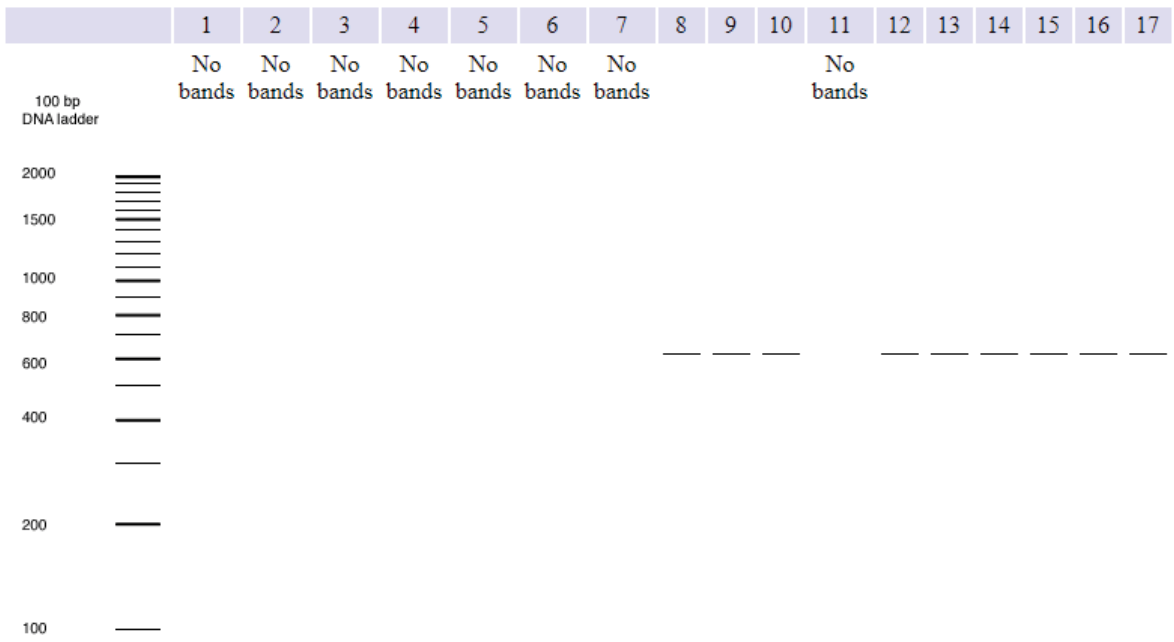

Figure 3: Detection of $c d t B$ gene. Isolates harbouring the gene gives a $620 \mathrm{bp}$ amplicon.

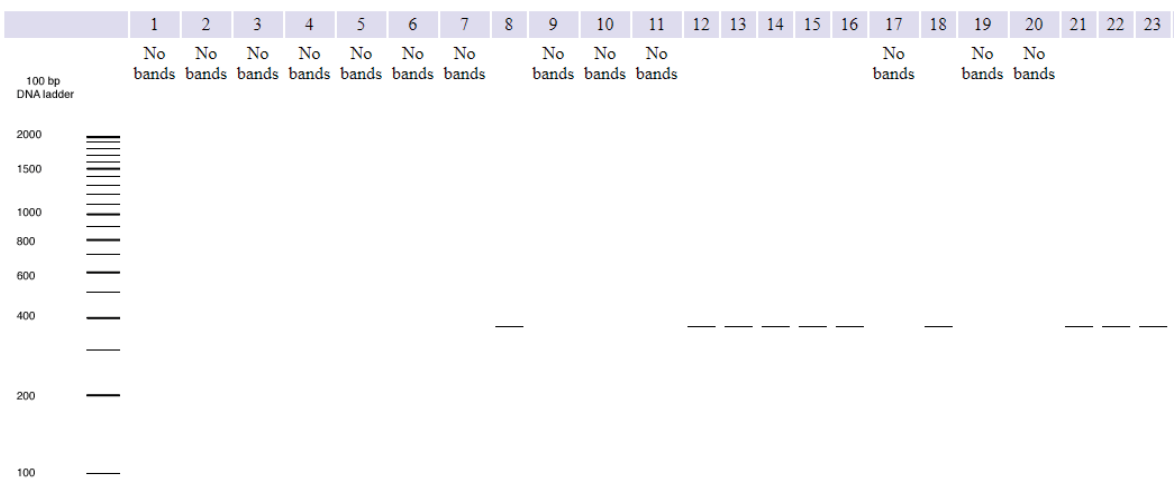

Figure 4: Detection of $c d t A$ gene. Isolates harbouring the gene gives a $370 \mathrm{bp}$ amplicon.

produced 562 bp gene product (Figure 7) while $30.77 \%$ isolates had the wlaN genes with 330 bp gene product (Figure 8). About 57.69\% isolates expressed waaC genes and gave 971 bp gene product (Figure 9). These three LOS associated genes were found in only $C$. jejuni strains. The $w l a N$ and $c g t B$ genes were not found in the same isolates. Similar results were also found in previous study [17]. Not all LOS associated genes were present in same genotype (Figure 10). Twenty-five percent isolates in genotype 2 expressed $c g t B$ and waaC genes. All the isolates in genotype 3 carried the waaC gene while about $61.54 \%$ isolates in genotype 3 expressed wlaN genes. About $14.29 \%$ isolates in genotype 4 carried both $\operatorname{cgt} B$ and waaC genes. Hence isolates from genotype 3 are more likely to exert their pathology through the mimicry of GM1 rather than GM2 whereas the reverse is true for isolates from genotype 2 and 4 . All isolates from genotype 3 would exhibit heptosyltransferase 
Citation: Nahar N, Rashid RB (2018) Genotypic Analysis of the Virulence and Antibiotic Resistance Genes in Campylobacter species in silico. J Bioanal Biomed 10: 13-23. doi:10.4172/1948-593X.1000199

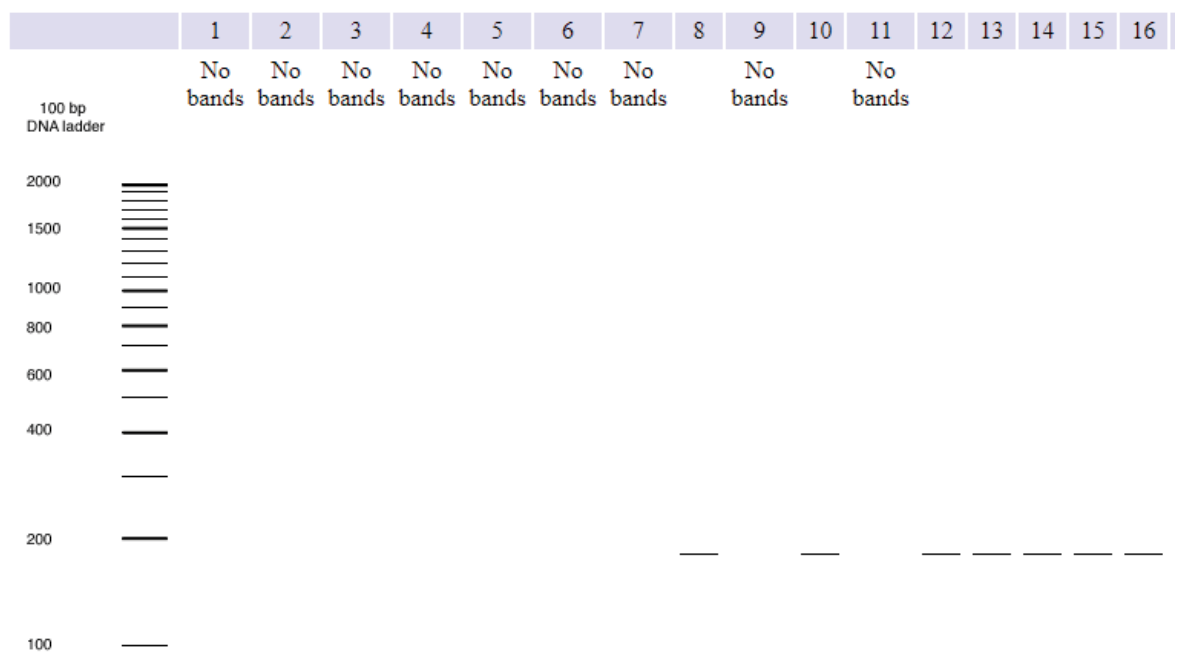

Figure 5: Detection of $c d t C$ gene. Isolates harbouring the gene gives a $182 \mathrm{bp}$ amplicon.

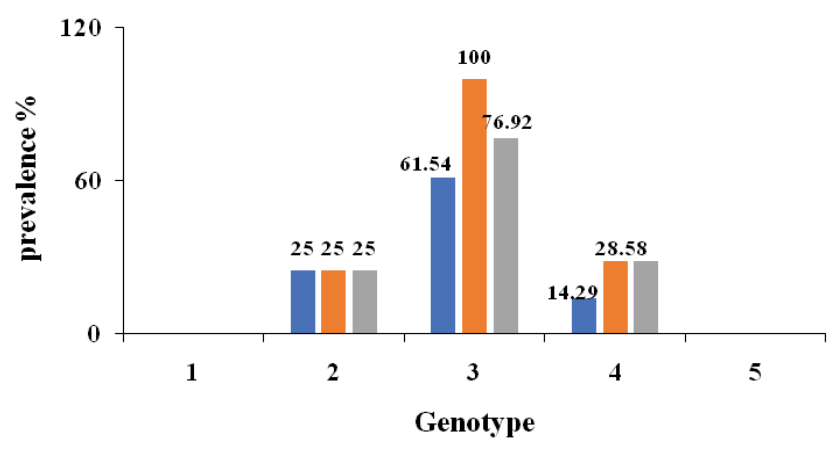

$\because \mathrm{catA} \%=\mathrm{CatB} \%=\mathrm{CatC} \%$

Figure 6: Genotypic distribution of $c d t$ genes. Genes encoding virulence genes are as follows: $c d t A$ : Cytolethal Distending Toxin A; $c d t B$ : Cytolethal Distending Toxin $\mathrm{B}$; cdtC: Cytolethal Distending Toxin C.

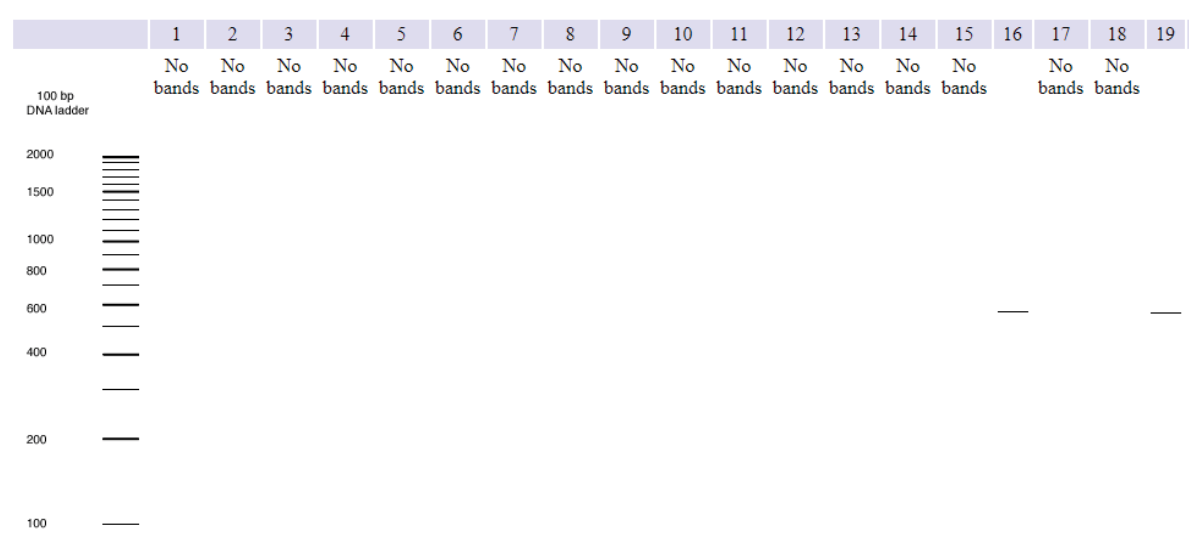

Figure 7: Detection of $c g t B$ gene. Isolates harbouring the gene gives a 562 bp amplicon.

I activity and would transfer first l-glycero-d-manno-heptose residue to the inner core of LOS.

\section{Genotypic distribution of adherence and invasion genes}

Invasion-associated marker (iam), genetic marker of Campylobacter species, identified in diarrhea and symptom free patients, was reported by previous study [47]. Previous study found that clinical samples in children didn't harbor iam gene but isolates from older patients had the iam genes [48]. The present study found no invasion associated marker, iam gene. In Brazil, diarrhoeagenic C. coli isolates were found in children that had the iam gene while low prevalence of iam genes were found in C. jejuni strains [49]. Invasion protein (ciaB), 
Citation: Nahar N, Rashid RB (2018) Genotypic Analysis of the Virulence and Antibiotic Resistance Genes in Campylobacter species in silico. J Bioanal Biomed 10: 13-23. doi:10.4172/1948-593X.1000199

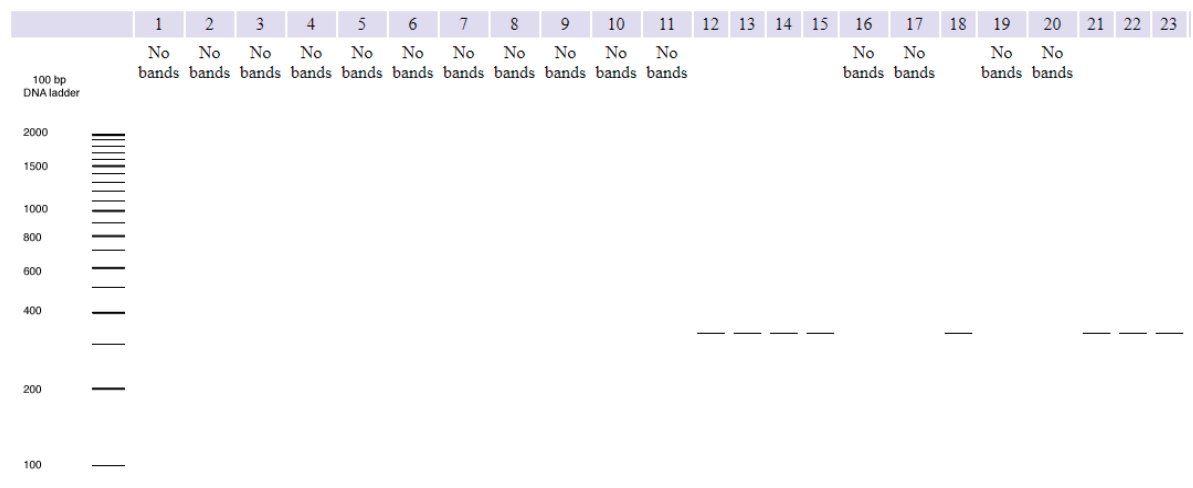

Figure 8: Detection of wlaN gene. Isolates harbouring the gene gives a $330 \mathrm{bp}$ amplicon

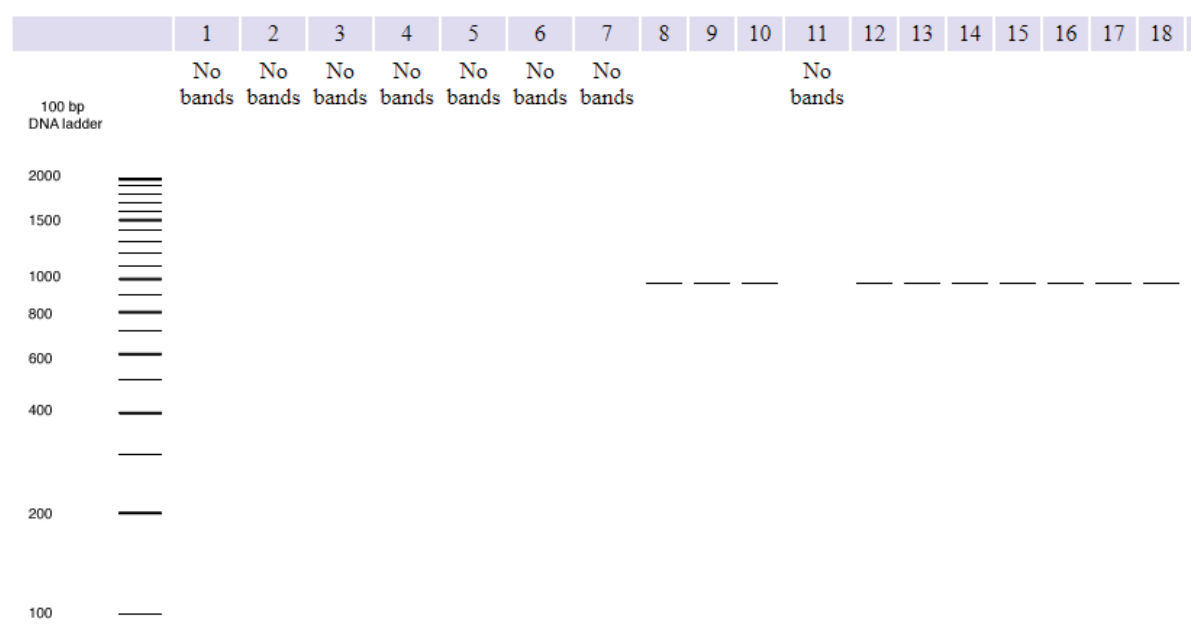

Figure 9: Detection of waaC gene. Isolates harbouring the gene gives a $971 \mathrm{bp}$ amplicon

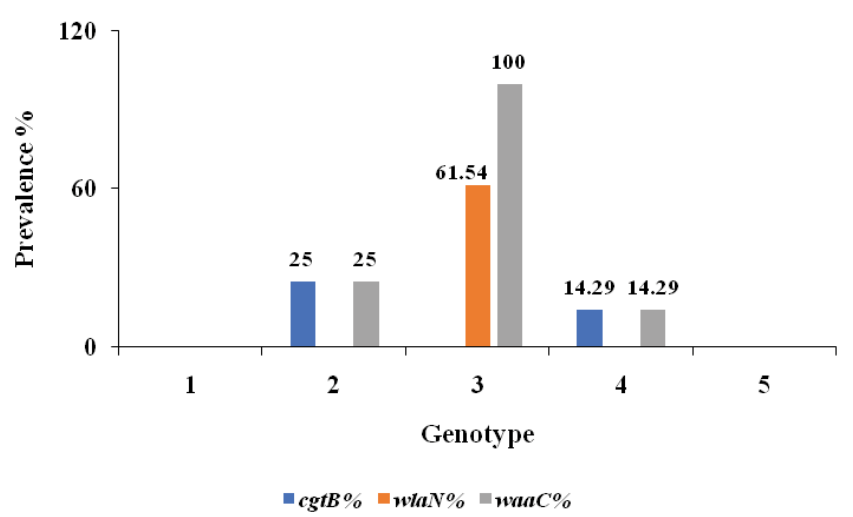

Figure 10: Genotypic distribution of $c g t B$, wlaN and waaC genes. Genes encoding virulence genes are as follows: cgtB: Campylobacterbeta1; 3 : Galactosyltransferase B Responsible for GM2 Mimicry; wlaN: $\beta$ : 1, 3 Galactosyltransferase Responsible GM1 Mimicry; waaC: Heptosyltransferase I.

outer membrane phospholipase A (pldA), and IV secretory protein (virB11) genes associated with bacterial invasion on epithelial cells, were found by previous study [22] but their functions are not well known. Phospholipase A, pldA was found to be involved in expression of invasion [23]. A study found that cattle isolates didn't harbour phospholipase A, pldA gene while sheep samples were potentially more virulent since carrying more iam genes than that of cattle isolates [50]. About $34.62 \%$ isolates $(n=9)$ had the pldA genes and produced
385 bp gene product (Figure 11) in C. jejuni strains. Previous study found that pldA gene was encountered in high number $(88-100 \%)$ in broiler samples [51]. High percentage (91.7\%) isolates from poultry feces contained pldA genes [52]. Several studies described that ciaB gene is associated with invasiveness and a play role in progression of the disease $[22,53]$. About $53.85 \%$ isolates $(n=14)$ had the ciaB genes with 527 bp gene product (Figure 12). Previously $98.80 \%$ and $61 \%$ isolates were found to harbor $c i a B$ and pldA genes, respectively 
Citation: Nahar N, Rashid RB (2018) Genotypic Analysis of the Virulence and Antibiotic Resistance Genes in Campylobacter species in silico. J Bioanal Biomed 10: 13-23. doi:10.4172/1948-593X.1000199

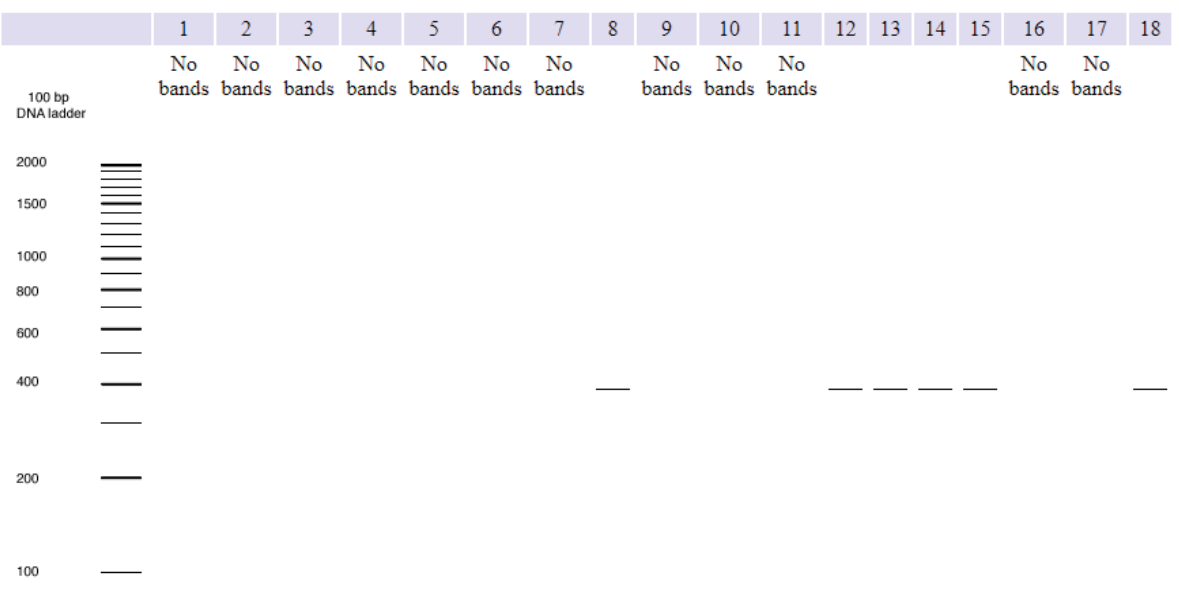

Figure 11: Detection of pldA gene. Isolates harbouring the gene gives a $385 \mathrm{bp}$ amplicon.

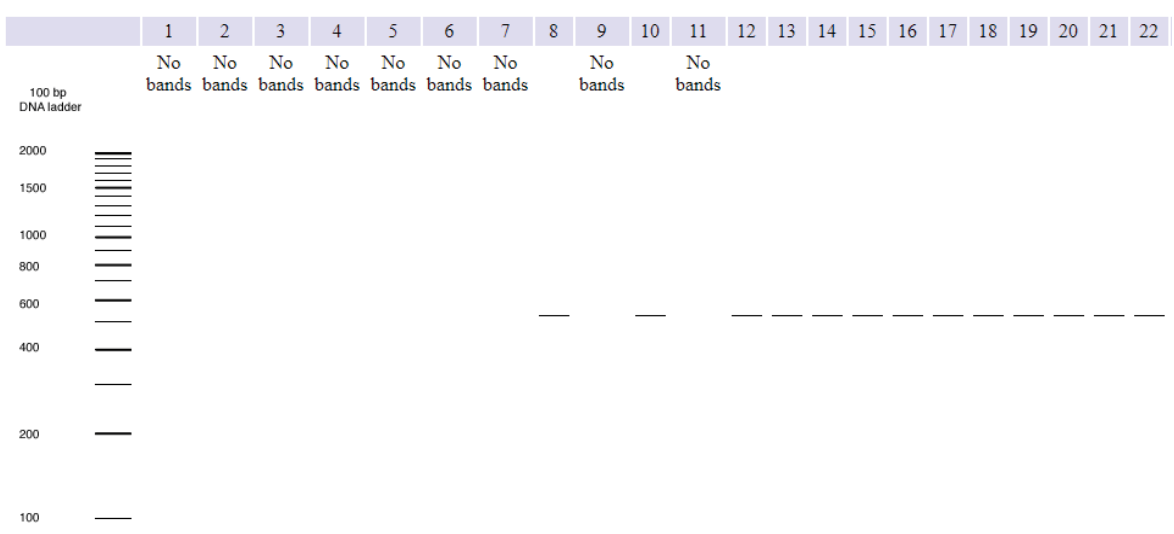

Figure 12: Detection of $c i a B$ gene. Isolates harbouring the gene gives a 527 bp amplicon.

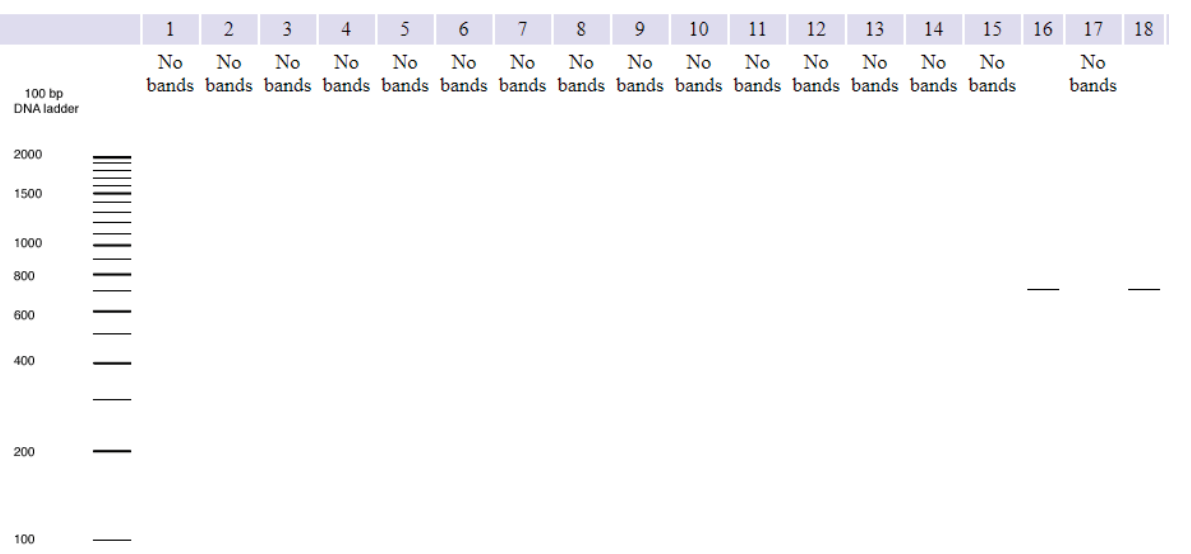

Figure 13: Detection of virB11 gene. Isolates harbouring the gene gives a $708 \mathrm{bp}$ amplicon.

[54]. Broiler meat samples and human strains equally harboured the plasmid associated virulence marker virB11 gene that could invade the human intestine [55]. Researchers found that very small subset of $C$. jejuni strains carried virB11 genes [39]. The virB11 gene was detected in two isolates (7.69\%) with 708 bp gene product (Figure 13). Nature of the plasmid and geographical differences are responsible for low level of virB11 gene [52]. Several studies also found very low number of virB11 genes in the tested isolates [51,56]. Genotype 3 contained all three genes described above (Figure 14). About $84.62 \%$ isolates in genotype 3 expressed ciaB genes while about $61.54 \%$ and $7.69 \%$ isolates in genotype 3 harboured pldA and virB11 genes, respectively. About $14.29 \%$ isolates in genotype 4 carried pld $A$ while about $28.58 \%$ isolates in genotype 4 carried $c i a B$ genes. Twenty-five percent isolates in genotype 2 harboured virB11 and ciaB genes. Hence it can be inferred 
Citation: Nahar N, Rashid RB (2018) Genotypic Analysis of the Virulence and Antibiotic Resistance Genes in Campylobacter species in silico. J Bioanal Biomed 10: 13-23. doi:10.4172/1948-593X.1000199

that invasion and adherence by isolates from genotype 2 are unlikely to be mediated by phospholipase A. The same can be stated invasion via virB11 invasion-associated marker for genotype 4 .

\section{Genotypic distribution of tetracycline resistance genes}

Tetracycline resistance gene tet $O$ was detected by using two primers named DMT1 and DMT2 as described previously [57]. Six isolates were found to harbor tetO resistance gene and gave $559 \mathrm{bp}$ gene product (Figure 15). Hence the prevalence was $23.08 \%$. Forty-six kilodalton membrane-bound efflux protein tetA exported tetracycline antibiotic from the cell [58]. Seven isolates (26.92\%) expressed tet $A$ gene with an approximate amplicon length of 486 bp (Figure 16). Six isolates expressed both tetO and tetA genes while Campylobacter jejuni subsp. jejuni M1 expressed only tetA resistance genes. Our data suggests that tetracycline resistance is more likely to be mediated due to $\operatorname{tet} A$ rather than $t e t O$. Our data agrees with a study also found that more Kenyan isolates harboured tet $A$ resistance genes rather than tet $O$ [43]. Twenty-five percent isolates in genotype 2 carried tet $O$ and $\operatorname{tet} A$

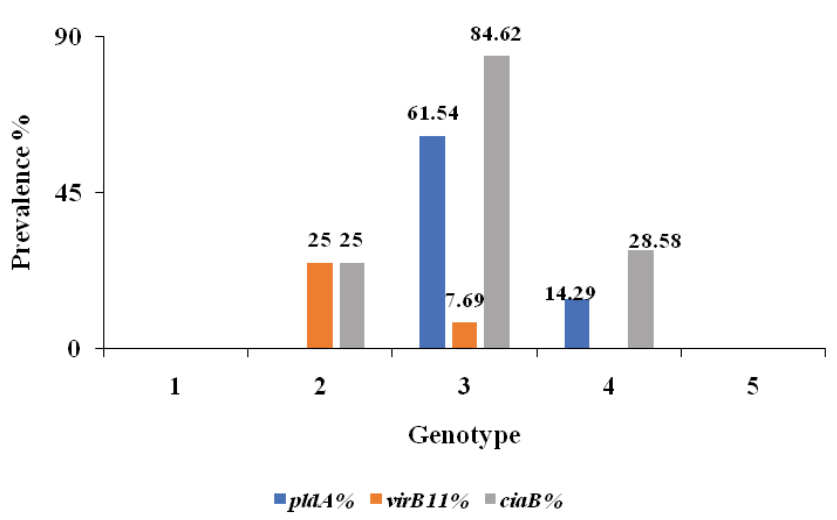

Figure 14: Genotypic distribution of pldA, virB11 and ciaB genes. Genes encoding virulence genes are as follows: pldA: Phospholipase A; virB11: Plasmid; pVir: Invasion Associated Marker; ciaB: Campylobacter Invasion Antigen B.

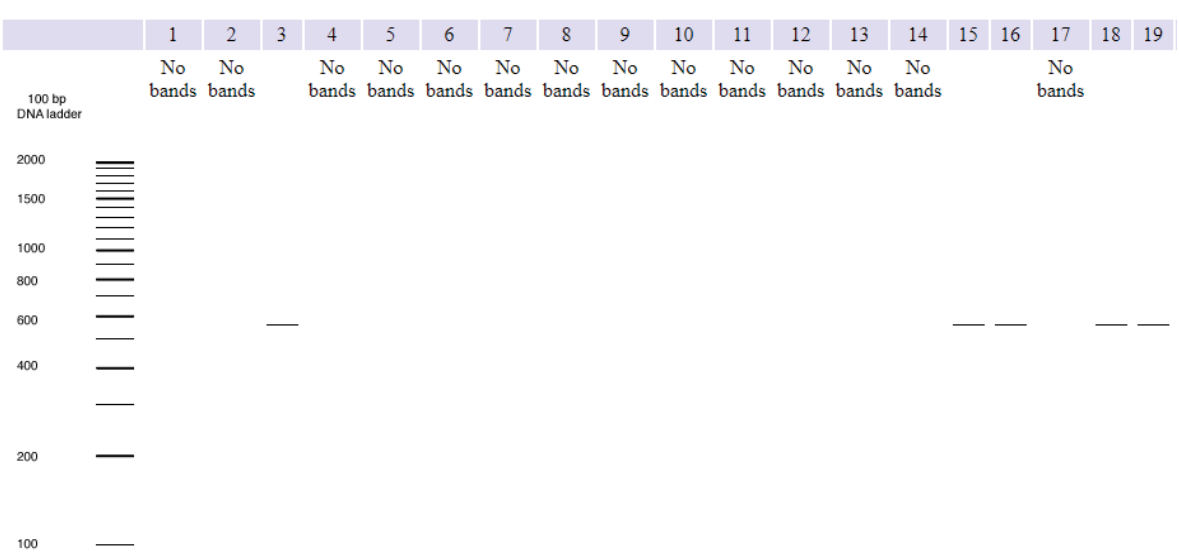

Figure 15: Detection of tetO gene. Isolates harbouring the gene gives a $559 \mathrm{bp}$ amplicon.

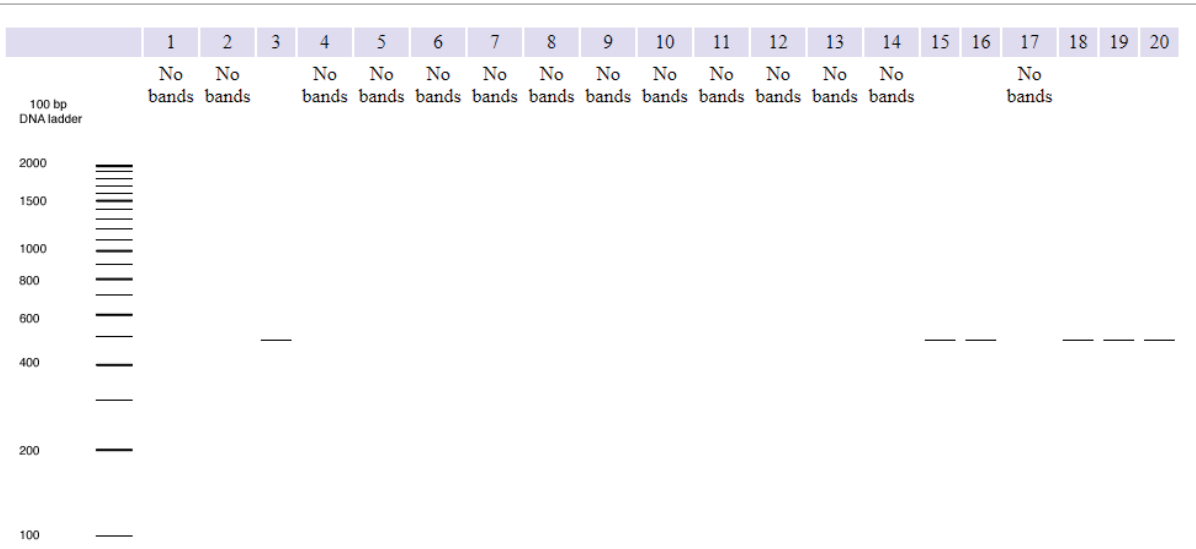

Figure 16: Detection of tetA gene. Isolates harbouring the gene gives a 486 bp amplicon. 


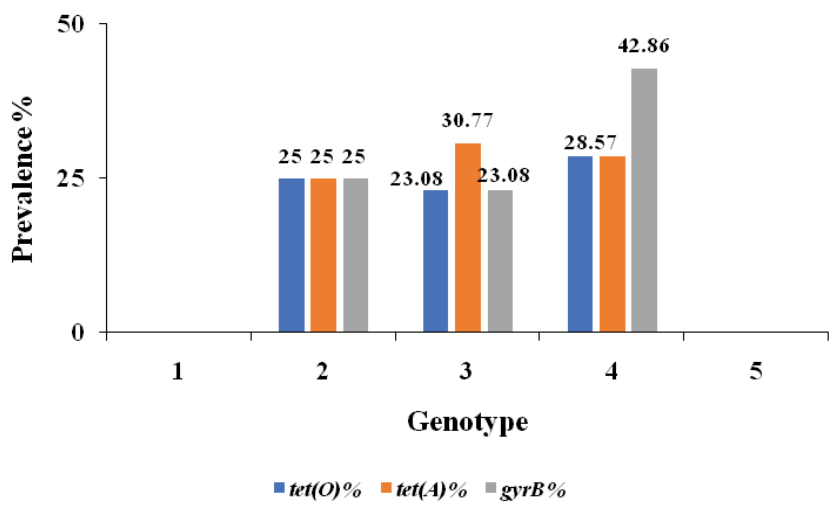

Figure 17: Genotypic distribution of tetracycline and fluoroquinolone resistance genes. Genes encoding resistance genes are as follows: tetA: Tetracycline Resistance Protein A; tetO: Tetracycline Resistance Protein O; gyrB: gyrB Subunit of DNA Gyrase.

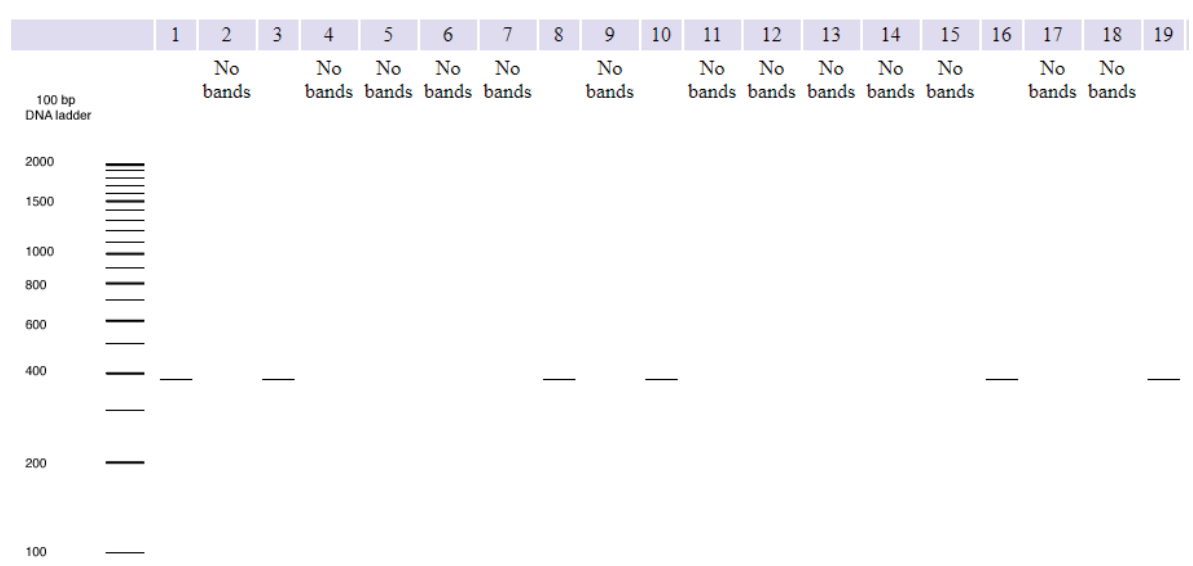

Figure 18: Detection of gyrB gene. Isolates harbouring the gene gives a 382 bp amplicon.

genes (Figure 17). About $23.08 \%$ isolates in genotype 3 expressed tet $O$ while $30.77 \%$ isolates in genotype 3 expressed tet $A$ genes. About $28.57 \%$ isolates in genotype 4 harboured tet $O$ and tet $A$ genes. Hence isolates from genotype 2 and genotype 4 are equally likely to be resistant to tetracycline due to efflux pump and ribosomal protection. However isolates from genotype 3 are more likely to be resistant due to efflux pump rather than ribosomal protection.

\section{Genotypic distribution of fluoroquinolone resistance genes}

The gyrA gene that conferred resistance to nalidixic acid or fluoroquinolone resistance was examined [30]. Present study found no gyrA gene positive isolates (not shown). Seven isolates (26.92\%) had the gyrB genes that conferred the resistance of fluoroquinolone antibiotics and gave $382 \mathrm{bp}$ gene products (Figure 18). Our study is a contrast to previous report which states that fewer isolates $(4.17 \%)$ were found to have silent mutations in $g y r B$ gene when compared to $g y r A$ gene [30]. Genotype 4 contained the highest number of gyrB genes (42.86\%) followed by genotype $2(25 \%)$ and genotype 3 (23.08\%) (Figure 17). Hence resistance to fluroquinolone in Campylobacter is more likely due to mutations in the gyrB subunit of DNA gyrase rather than the gyrA subunit.

\section{Conclusion}

Our study used bioinformatics aided approach to genotype and detect virulence and antibiotic resistance genes. Pulsed Field Gel Electrophoresis (PFGE) is considered as the gold standard for genotyping
[34] and in silico data matched to that obtained in conventional method [35]. The summary of the results have been illustrated in Table 4. We concluded that there is variation in prevalence across the genotypes. Certain genotypes are more threatening than others. Our data isolates from genotype 1 and 5 are not pathogenic since it didn't harbor any of gastroenteritis toxin genes $(c d t A, c d t B, c d t C)$, genes associated with Guillain-Barré syndrome (wlaN, cgtB, waaC) or genes associated with adherence and invasiveness (iam, pldA, virB11, ciaB). These genotypes did not have genes associated with fluoroquinolone and tetracycline resistance. The cytolethal distending toxin genes has a higher prevalence in genotype 3. Since cdtB alone can exert cytotoxicity, all isolates from genotype 3 are capable of causing gastroenteritis. Based on the difference in the prevalence of Guillain-Barré syndrome associated genes among the genotypes, isolates from genotype 3 are more likely to exert their pathology through the mimicry of GM1 rather than GM2 whereas the reverse is true for isolates from genotype 2 and 4 . All isolates from genotype 3 would exhibit heptosyltransferase I activity and would modify the inner core of LOS. Our data also suggests that that invasion and adherence by isolates from genotype 2 are unlikely to be mediated by phospholipase $A$. The same can be stated invasion via virB11 invasion-associated marker for genotype 4 . The mechanism of drug resistance also varies across the genotype. Isolates from genotype 2 and genotype 4 are equally likely to be resistant to tetracycline due to efflux pump and ribosomal protection. However isolates from genotype 3 are more likely to be resistant due to efflux pump rather than ribosomal protection. As for resistance to fluoroquinolone resistance isolates 
Citation: Nahar N, Rashid RB (2018) Genotypic Analysis of the Virulence and Antibiotic Resistance Genes in Campylobacter species in silico. J Bioanal Biomed 10: 13-23. doi:10.4172/1948-593X.1000199

from genotype 4 are the most resistant. All resistant isolates carry a mutated gyrB subunit of DNA gyrase rather than a mutated gyrA subunit. Campylobacter shows resistance to the clinically important antibiotics and this rising trend is a concern for public health. Therefore, enhanced research efforts are needed to understand the transmission, persistence and prevention of antibiotic-resistant Campylobacter. Campylobacter species acquired antibiotic resistance gene by horizontal gene transfer from either Streptomyces, Streptococcus, or Enterococcus species [59]. Seventy-five to seventy-six percent sequence homology was found between tetO gene of Campylobacter and tetM of Streptococcus pneumoniae. The virulence and resistance profile of future isolates with known genotype can be predicted according to our data. Additional studies are needed to understand how antibiotic resistant Campylobacter emerge under selective pressure. Application of advanced approaches, such as genomics and proteomics, is expected to provide new insights into the molecular mechanisms involved in the development of antibiotic resistance in Campylobacter. Good hygiene practice and food safety assurance programs should be implemented to reduce the contamination risk during handling and processing. Misuse of antibiotics in animal feed must be reduced to control antibioticresistant Campylobacter.

\section{References}

1. Fraqueza MJ, Ribeiro SA, Pereira SC, Fernandes MH, Fernandes MJ, et al (2016) Genetic and antibiotic resistance profiles of thermophilic Campylobacter spp. isolated from quails (Coturnixcoturnix japonica) in a Portuguese slaughterhouse. Food Control 59: 337-344.

2. World Health Organization (WHO) (2013) The global view of campylobacteriosis: Report of an expert consultation. Utrecht, Netherlands.

3. Ruiz-Palacios GM (2007) The health burden of Campylobacter infection and the impact of antimicrobial resistance: Playing chicken. Clin Infect Dis 44: 701 703.

4. Dingle KE, Colles FM, Wareing DR, Ure R, Fox AJ, et al. (2001) Multilocus sequence typing system for Campylobacter jejuni. J Clin Microbiol 39: 14-23.

5. Zhong X, Wu Q, Zhang J, Shen S (2016) Prevalence, genetic diversity and antimicrobial susceptibility of Campylobacter jejuni isolated from retail food in China. Food Control 62: 10-15.

6. Hafez HM (2003) Bacterial contaminations and risks from poultry meat and eggs. Arch Geflüglk 67: 146-152.

7. EFSA (2015) The European Union summary report on trends and sources of zoonoses, zoonotic agents and food-borne outbreaks in 2012. EFSA J 12:3547.

8. Weijtens MJ, van der Plas J, Bijker PG, Urlings HA, Koster D, et al. (1997) The transmission of Campylobacter in piggeries: An epidemiological study. J Appl Microbiol 83: 693-698.

9. Gill CO, Badoni M, McGinnis JC (1999) Assessment of the adequacy of cleaning of equipment used for breaking beef carcasses. Int J Food Microbiol 46: 1-8.

10. Gill CO, McGinnis JC, Bryant J (2001) Contamination of beef chucks with Escherichia coli during carcass breaking. J Food Prot 64: 1824-1827.

11. Dasti JI, Tareen AM, Lugert R, Zautner AE, Gross U (2010) Campylobacter jejuni: A brief overview on pathogenecity-associated factors and diseasemediating mechanism. Int J Med Microbiol 300: 205-211.

12. Datta S, Niwa H, Itoh K (2003) Prevalence of 11 pathogenic genes of Campylobacter jejuni by PCR in strains isolated from humans, poultry meat and broiler and bovine faeces. J Med Microbiol 52: 345-348.

13. Johnson WM, Lior H (1988) A new heat-labile cytolethal distending toxin (CLDT) produced by Campylobacter spp. Microb Pathog 4: 115-126.

14. Lara-Tejero M, Galán JE (2001) CdtA, CdtB, and CdtC form a tripartite complex that is required for cytolethal distending toxin activity. Inf Immun 69: 4358-4365.

15. Jeon B, Itoh K, Ryu S (2005) Promoter analysis of cytolethal distending toxin genes (cdtA , B, and C ) and effect of a luxS mutation on CDT production in Campylobacter jejuni. Microbiol Immunol 49: 599-603.
16. Smith JL, Bayles DO (2006) The contribution of cytolethal distending toxin to bacterial pathogenesis. Crit Rev Microbiol 32: 227-248.

17. Müller J, Schulze F, Müller W, Hänel I (2006) PCR detection of virulenceassociated genes in Campylobacter jejuni strains with differential ability to invade Caco-2 cells and to colonize the chick gut. Vet Microbiol 113: 123-129.

18. Linton D, Gilbert M, Hitchen PG, Dell A, Morris HR, et al. (2000) Phase variation of a beta-1, 3 galactosyltransferase involved in generation of the ganglioside GM1-like lipo-oligosaccharide of Campylobacter jejuni. Mol Microbiol 37: 501 514

19. Gilbert M, Brisson JR, Karwaski MF, Michniewicz J, Cunningham AM, et al (2000) Biosynthesis of ganglioside mimics in Campylobacter jejuni OH4384 Identification of the glycosyltransferase genes, enzymatic synthesis of model compounds, and characterization of nanomole amounts by $600-\mathrm{mhz}(1) \mathrm{h}$ and (13)c NMR analysis. J Biol Chem 275: 3896-3906.

20. Klena JD, Gray SA, Konkel ME (1998) Cloning, sequencing, and characterization of the lipopolysaccharide biosynthetic enzyme heptosyltransferase I gene (waaC) from Campylobacter jejuni and Campylobacter coli. Gene 222: 177185.

21. Antoine T1, Priem B, Heyraud A, Greffe L, Gilbert M, et al. (2003) Large-scale in vivo synthesis of the carbohydrate moieties of gangliosides GM1 and GM2 by metabolically engineered Escherichia coli. Chembiochem 4: 406-412.

22. Konkel ME, Kim BJ, Rivera-Amill V, Garvis SG (1999) Bacterial secreted proteins are required for the internaliztion of Campylobacter jejuni into cultured mammalian cells. Mol Microbiol 32: 691-701.

23. Ziprin RL, Young CR, Byrd JA, Stanker LH, Hume ME, et al. (2001) Role of Campylobacter jejuni potential virulence genes in cecal colonization. Avi Dis 45: 549-557.

24. Abdollahpour N, Zendehbad B, Alipour A, Khayatzadeh J (2015) Wild-bird feces as a source of Campylobacter jejuni infection in children's playgrounds in Iran. Food Control 50: 378-381.

25. Chen X, Naren GW, Wu CM, Wang Y, Dai L, et al. (2010) Prevalence and antimicrobial resistance of Campylobacter isolates in broilers from China. Vet Microbiol 144: 133-139.

26. Allos BM (2001) Campylobacter jejuni Infections: update on emerging issues and trends. Clin Infect Dis 32: 1201-1206.

27. Kashoma IPB, Kassem II, John J, Kessy B, Gebreyes W, et al. (2015) Prevalence and antimicrobial resistance of Campylobacter isolated from dressed beef carcasses and raw milk in Tanzania. Microb Drug Resist 22: 4052.

28. Gouvêa R, dos Santos FF, de Aquino MHC (2015) Fluoroquinolones in industrial poultry production, bacterial resistance and food residues: A review. Rev Bras Ciênc Avíc 17: 1-10.

29. González I, Georgiou M, Alcaide F, Balas D, Liñares J, et al. (1998) Fluoroquinolone resistance mutations in the parC, parE, and gyrA genes of clinical isolates of viridans group streptococci. Antimicrob Agents Chemother 42: $2792-2798$.

30. Piddock LJ, Ricci V, Pumbwe L, Everett MJ, Griggs DJ (2003) Fluoroquinolone resistance in Campylobacter species from man and animals: Detection of mutations in topoisomerase genes. J Antimicrob Chemother 51: 19-26.

31. Roberts MC (2011) Environmental macrolide-lincosamide-streptogramin and tetracycline resistant bacteria. Front Microbiol 2: 40.

32. Connell SR, Tracz DM, Nierhaus KH, Taylor DY (2003) Ribosomal protection proteins and their mechanism of tetracycline resistance. Antimicrob Agents Chemother 47: 3675-3681.

33. Chopra I (1985) Mode of action of the tetracyclines and the nature of bacterial resistance to them. Handb Exp Pharmacol pp: 317-392.

34. Peters TM (2009) Pulsed-field gel electrophoresis for molecular epidemiology of food pathogens. Methods Mol Biol 59-70.

35. Bikandi J, San Millán R, Rementeria A, Garaizar J (2004) In silico analysis of complete bacterial genomes: PCR, AFLP-PCR and endonuclease restriction. Bioinformatics 20: 798-799.

36. Hickey TE, McVeigh AL, Scott DA, Michielutti RE, Bixby A, et al. (2000) Campylobacter jejuni cytolethal distending toxin mediates release of interleukin-8 from intestinal epithelial cells. Infect Immun 68: 6535-6541. 
Citation: Nahar N, Rashid RB (2018) Genotypic Analysis of the Virulence and Antibiotic Resistance Genes in Campylobacter species in silico. J Bioanal Biomed 10: 13-23. doi:10.4172/1948-593X.1000199

37. Wassenaar TM, Wagenaar JA, Rigter A, Fearnley C, Newell DG, et al. (2002) Homonucleotide stretches in chromosomal DNA of Campylobacter jejuni display high frequency polymorphism as detected by direct PCR analysis. FEMS Microbiol Lett 212: 77-85.

38. Godschalk PC, van Belkum A, van den Braak N, van Netten D, Ang CW, et al. (2007) PCR-restriction fragment length polymorphism analysis of Campylobacter jejuni genes involved in lipooligosaccharide biosynthesis identifies putative molecular markers for Guillain-Barré syndrome. J Clin Microbiol 45: 2316-2320.

39. Bacon DJ, Alm RA, Burr DH, Hu L, Kopecko DJ, et al. (2000) Involvement of a plasmid in virulence of Campylobacter jejuni 81-176. Infect Immun 68 4384-4390.

40. Zheng J, Meng J, Zhao S, Singh R, Song W (2006) Adherence to and invasion of human intestinal epithelial cells by Campylobacter jejuni and Campylobacter coli isolates from retail meat products. J Food Prot 69: 768-774.

41. Korsak D, Dzierzanowska-Fangrat K, Popowski J, Rozynek E (2004) Prevalence of potential virulence markers iam in Campylobacter jejuni and Campylobacter coli isolates obtained from chicken carcasses (in Polish). Rocz Panstw Zakl Hig 55: 307-312.

42. International Standards Organization (2006) ISO 10272-1:2006 Microbiology of food and animal feeding stuffs-horizontal method for detection and enumeration of Campylobacter spp. Part 1: detection method.

43. Nguyen TNM, Hotzel H, Njeru J, Mwituria J, El-Adawy H (2016) Antimicrobial resistance of Campylobacter isolates from small scale and backyard chicken in Kenya. Gut Pathog 8: 39.

44. San Millán RM, Martínez-Ballesteros I, Rementeria A, Garaizar J, Bikandi J (2013) Online exercise for the design and simulation of PCR and PCR-RFLP experiments. BMC Res Notes 6: 513.

45. Abuoun M, Manning G, Cawthraw SA, Ridley A, Ahmed IH, et al. (2005) Cytolethal distending toxin (CDT)-negative Campylobacter jejuni strains and anti-CDT neutralizing antibodies are induced during human infection but not during colonization in chickens. Infect Immun 73: 3053-3062.

46. Lara-Tejero M, Galan JE (2000) A bacterial toxin that controls cell cycle progression as a deoxyribonuclease I-like protein. Science 290: 354-357.

47. Carvalho ACT, Ruiz-Palacios GM, Ramos-Cervantes $P$, Cervantes LE, Jiang $X$, et al. (2001) Molecular characterization of invasive and non-invasive Campylobacter jejuni and Campylobacter coli isolates. J Clin Microbiol 39: 1353-1359.

48. Al-Mahmeed A, Senok AC, Ismaeel AY, Bindayna KM, Tabbara KS, et al.
(2006) Clinical relevance of virulence genes in Campylobacter jejuni isolates in Bahrain. J Med Microbiol 55: 839-843.

49. Andrzejewska M1, Klawe JJ, SzczepaÅ,ska B, Spica D (2011) Occurrence of virulence genes among Campylobacter jejuni and Campylobacter coli isolates from domestic animals and children. Pol J Vet Sci 14: 207-211.

50. Khoshbakht R, Tabatabaei M, ShirzadAski H, Hosseinzadeh S (2014) Occurrence of virulence genes and strain diversity of thermophilic campylobacters isolated from cattle and sheep faecal samples. Iranian J Vet Res 15: 138-144.

51. Datta S, Niwa H, Itoh K (2009) Age-dependent variation of virulence-associated genes retained in Campylobacter jejuni isolated from chickens in a poultry farm. J Vet Med Sci 71: 1247-1249.

52. Khoshbakht R, Tabatabaei M, Hosseinzadeh S, Shekarforoush SS, ShirzadAski H (2013) Distribution of nine virulence-associated genes in Campylobacter jejuni and $C$ coli isolated from broiler feces in Shiraz, Southern Iran. Foodborne Pathog Dis 10: 764-770.

53. Rivera-Amill V1, Kim BJ, Seshu J, Konkel ME (2001) Secretion of the virulenceassociated Campylobacter invasion antigens from Campylobacter jejuni requires a stimulatory signal. J Infect Dis 183: 1607-1616.

54. Feodoroff B, Ellström P, Hyytiäinen H, Sarna S, Hänninen ML, et al. (2010) Campylobacter jejuni isolates in Finnish patients differ according to the origin of infection. Gut Pathog 2: 22.

55. González-Hein G, Huaracán B, García P, Figueroa G (2014) Prevalence of virulence genes in strains of Campylobacter jejuni isolated from human, bovine and broiler. Braz J Microbiol 44: 1223-1229.

56. Bang DD, Scheutz F, Ahrens P, Pedersen K, Blom J, et al. 2001. Prevalence of cytolethal distending toxin (cdt) genes and CDT production in Campylobacter spp. isolated from Danish broilers. J Med Microbiol 50: 1087-1094.

57. Mazi W, Senok AC, Al-Mahmeed A, Arzese A, Bindayna, K, et al. (2008) Trends in antibiotic sensitivity pattern and molecular detection of tet(O)-mediated tetracycline resistance in Campylobacter jejuni isolates from human and poultry sources. Jpn J Infect Dis 61: 82-84.

58. Chopra I, Roberts M (2001) Tetracyline antibiotics: mode of action, applications, molecular biology, and epidemiology of bacterial resistance. Microbiol Mol Rev 62: $232-260$.

59. Batchelor RA, Pearson BM, Friis LM, Guerry P, Wells JM (2004) Nucleotide sequences and comparison of two large conjugative plasmids from different Campylobacter species. Microbiology 150: 3507-3517. 